\title{
Reconfiguring and Remediating Social Media as Alternative Media: Exploring Youth Activists' Digital Media Ecology in El Salvador
}

\section{Summer Harlow ${ }^{1}$}

Recepción: 2016-08-25

Aceptación por pares: 2016-09-27
Envío a pares: 2016-09-01

Aprobación: 2016-09-28

\section{DOI: 10.5294/pacla.2016.19.4.3}

Para citar este artículo / To reference this article / Para citar este artigo Harlow, S. (2016). Reconfiguring and remediating social media as alternative media: Exploring youth activists' digital media ecology in El Salvador. Palabra Clave, 19(4), 997-1026. DOI: 10.5294/pacla.2016.19.4.3

\section{Abstract}

This ethnographic case study examined how the Salvadoran youth activist group Activista incorporated social media into its media ecology. Analysis revealed four main themes: social media as alternative media; the relationship between Facebook and visibility, legitimacy, and community; a social media divide; and the challenges of the digital divide and a lack of a social media strategy. This study showed how, despite digital inequalities, Activista reconfigured and remediated digital and analog tools and tactics, thus reconfiguring and remediating their relationship with journalists and social media users at large. Ultimately Activista managed to use social media as a mediated, hybridized, multi-dimensional mode of communication, contributing to our

1 Florida State University. Estados Unidos. sharlow@fsu.edu 
understanding of hyper-mediation and the way the digital and the analog work together in a social movement's media culture within a digitally divided country.

\section{Keywords}

Activism; El Salvador; ethnography; media ecology; mediations; social media (Source: Unesco Thesaurus). 


\section{Reconfiguración y remediación de los medios sociales como medios alternativos: explorando la ecología de los medios digitales de los jóvenes activistas en El Salvador}

\section{Resumen}

Este estudio de caso etnográfico examinó cómo el grupo de activistas juveniles salvadoreños, Activista, incorporó los medios de comunicación sociales en su ecología de medios. El análisis reveló cuatro temas principales: los medios de comunicación social como medios alternativos; la relación entre Facebook y la visibilidad, la legitimidad y la comunidad; una brecha de los medios de comunicación social; y los desafíos de la brecha digital y una falta de estrategia de medios sociales. Este estudio mostró cómo, a pesar de las desigualdades digitales, Activista reconfiguró y remedió las herramientas digitales y analógicas y las tácticas, reconfigurando y remediando así su relación con los periodistas y los usuarios de los medios sociales en general. Finalmente, Activista logró utilizar los medios sociales como un modelo de comunicación multidimensional, hibridizado y mediado, contribuyendo a nuestra comprensión de la hipermediación y la forma en la que lo digital y lo analógico trabajan juntos en una cultura de medios del movimiento social en un país dividido digitalmente.

\section{Palabras clave}

Activismo; El Salvador; Etnografía; ecología de los medios de comunicación; mediaciones; medios de comunicación sociales (Fuente: Tesauro de la Unesco). 


\section{Reconfiguração e remediação das mídias sociais como meios alternativos: explorando a ecologia da mídia digital dos jovens ativistas em El Salvador}

\section{Resumo}

Este estudo de caso etnográfico, analisou como o grupo de jovens ativistas salvadorenhos, Activista, incorporou a mídia social em sua ecologia das mídias. A análise revelou quatro temas principais: as mídias sociais como mídias alternativas; a relação entre o Facebook e a visibilidade, a legitimidade e a comunidade; uma divisão das mídias sociais; e os desafios da divisão digital e a falta de estratégia de mídias sociais. Este estudo mostrou como, apesar das desigualdades digitais, Activista reconfigurou e remediou as ferramentas digitais e analógicas e as táticas, reconfigurando e remediando o seu relacionamento com os jornalistas e os usuários de redes sociais em geral. Finalmente, Activista conseguiu usar as mídias sociais como um modelo de comunicação multidimensional, hibridizado e mediado, contribuindo para a nossa compreensão da hipermediação e da maneira em que o digital e analógico trabalham juntos em uma cultura de mídia do movimento social em um país digitalmente dividido.

\section{Palavras-chave}

Ativismo; El Salvador; etnografia; ecologia da mídia; mediações; mídias sociais (Fonte: Tesauro da Unesco). 
About 20 youth from throughout Central America, in their late teens and early 20s, sat outside on a patio under fans, discussing ways to get young people from El Salvador involved in their clean-water campaign. They had spent the prior month in an intense Cambio Global (Global Change) course, sponsored by international NGO ActionAid's Salvadoran office, where they learned how to create an activist campaign. As part of the Cambio Global course, participants learned how to write for a blog, and shoot and edit basic videos. As they learned how to organize a campaign, they learned both offline and online techniques, and were taught that the two go hand-inhand. Now these young activists were preparing to launch their Todos Somos Agua (We are All Water) campaign in the capital city of San Salvador.

"We could do a flash mob," one male Salvadoran teen suggested. "Break dance," another offered.

The suggestions kept coming: dress as clowns, be mimes, pretend to be statues, do the Harlem Shake dance, conduct a graffiti workshop, have supporters change their Facebook profile pictures to show themselves holding a water drop-shaped poster with the campaign's logo.

What about a good old-fashioned march?, someone asked, giving the group pause. They were so caught up in suggesting creative forms of protest that they had not even thought about traditional types of collective action. Eventually, they decided that whatever they did needed to be unique enough to grab the media's attention. And whatever they did, online social media was necessary. After all, they said, look at the way Facebook and Twitter led to a revolution in Egypt.

While these activists might have overblown the role of social media in the Arab Spring, studies increasingly indicate that online social networking sites are now fundamentally linked with recent protest activity around the world, including Latin America (Anduiza et al., 2013; Bennett \& Segerberg, 2011; Valenzuela et al., 2012). Considering that empirical evidence shows that online social media have a positive mobilizing impact on civic participation, including protest behaviors (Macafee \& De Simone, 2012; Tufekci 
\&Wilson; 2012; Wilson \& Dunn, 2011), this ethnographic case study of the Salvadoran-based Todos Somos Agua campaign led by the Activista (Activist) youth group explores the possibilities, benefits, challenges, and risks of operating within a digital media ecology and using online social media for social change. Furthermore, in light of the fact that the mainstream Salvadoran press has evolved into a conservative, elitist media system (Pérez \& Carballo, 2013) that prioritizes business and political elites' interests over those of ordinary citizens (Rockwell \& Janus, 2003), this research considers the relationship between activists and digital, alternative media and traditional, mainstream media, examining whether online social media like Facebook can challenge, even undermine, mainstream media.

Broadly, this study poses two main research questions:

- How do Salvadoran activists view their relationship to social media, alternative media, and mainstream media?

- What are the perceived values, drawbacks, and challenges of using online social media for social change?

Through a lens of social movement media culture (Costanza-Chock, 2012), which addresses Mattoni and Trerés (2014) concerns about too much research focused on one medium or the latest digital advance, this study answers these broad questions using Lievrouw's (2011) concept of remediation and reconfiguration to explore Activista's use of new technologies and what that means for our understanding of alternative media and social change in a digital era. Such a study is important for illuminating the links between a social movement's ecology and the ever-changing media ecology, especially in a developing country with steep digital inequalities like El Salvador.

\section{Literature and Theoretical Framework}

\section{Alternative and activists' media}

Previous research shows that the activist-journalist relationship is a complex one. Gamson and Wolfsfeld (1993) noted an imbalance in the media-move- 
ment relationship, as movements depend on the media for "mobilization, validation, and scope enlargement" (p. 116). Activists traditionally have found themselves in an adversarial role when it comes to mainstream media, which "privilege dominant, mainstream positions" (Gurevitch \& Blumler, 1990, p. 33) and ignore ordinary citizen voices, especially when those voices are seen to oppose hegemonic power structures (Downing, 2001; Rodriguez, 2001). Hall (1986) noted the way hegemonic ideologies are "encoded" into mainstream media texts, furthering the interests of society's dominant classes and marginalizing groups according to race, class, gender, and other social categorizations. Numerous studies point to a pattern of media coverage, referred to as the "protest paradigm" (Chan \& Lee, 1984; McLeod \& Hertog, 1999), that serves to delegitimize protesters and their causes, and support the status quo (McLeod, 2007; Gitlin, 1980; McLeod \& Hertog, 1992). The way in which the media portray protesters is an important indicator for whether the public will accept and support them and their cause (McLeod \& Hertog, 1992; McLeod \& Detenber, 1999).

Faced with such delegitimizing portrayals in mainstream media, social movement actors, protesters, and other marginalized sectors of society traditionally responded by taking control of their messages and creating their own media, whether leaflets and newsletters, community radio programming, or, more recently, blogs and other digital media content (Gitlin, 1980; Kessler, 1984; Downing, 2001; Kidd, 2003). Such “dissident media” (Kessler, 1984) often is subsumed under the broad heading of "alternative" media. Scholars define alternative media as oppositional media representing and serving the interests of groups marginalized by the mainstream media. Leading alternative media scholar John Downing (2001) considers alternative media to be counter-hegemonic "radical" media, interdependent with social movements. Downing's Gramscian-inspired emphasis on counter-hegemonic resistance explicitly links radical alternative media to power and oppression, as "radical alternative media serve as developmental power agents" (2001, p. 44). Rodríguez's (2001) notion of “citizens' media," which builds on Downing's conception of radical media, suggests that ordinary citizens' participation in media production and consumption processes can change or validate an individual's concept of the "self," thereby contesting hegemonic 
power structures through the very process of media intervention. Couldry and Curran (2003) focus on alternative media as "media production that challenges, at least implicitly, actual concentrations of media power" (p. 7). For these scholars, "media power is an emergent form of social power” (Couldry \& Curran, 2003, p. 4). Similarly, Simpson Grinberg (1986) viewed alternative communication in Latin America as a form of "social resistance," as "this form of communication constitutes an alternative to the dominant discourse of power at all levels" (p. 169). Other Latin American scholars see alternative media as offering counter information and opposition to the status quo, aimed at political transformation (Sel, 2009; Vinelli \& Rodríguez Esperón, 2004).

The advent of Web 2.0, and online social media in particular, seems to have renewed interest in alternative media research, with scholars exploring how digital technologies are blurring the lines between media producers and consumers, and even alternative and mainstream media. Lievrouw (2011), who like Downing (2001) sees communication processes and social movements as intertwined, identified alternative/activist new media as those that "employ or modify communication artifacts, practices, and social arrangements of new information and communication technologies to challenge or alter dominant, expected, or accepted ways of doing society, culture, and politics" (p. 19). Ultimately, for Lievrouw, information communication technology represents more than just a medium or a tool for activists, but rather new media "might in fact constitute movements and action in themselves" (2011, p. 157).

\section{Online social media and activism}

The use of digital tools, including email, social media, blogs, podcasts, and video-sharing platforms, among alternative media and activists to create campaigns, online petitions, virtual sit-ins, and interactive communities, have become common place in recent years. These tools give "movements and activists the power of mass communication" (Postmes \& Brunsting, 2002, p. 294). Scholars often tout the Internet for its creation of new spaces for public discourse (Beers, 2006), or what Fraser (1990) referred to as counter public spheres. In her critique of Haber- 
mas' (1989 [1962]) original romanticized notion of a public sphere, Fraser (1990) suggested that the exclusion of marginalized groups from the male- and elite-dominated universal public sphere leads to the creation of multiple, subaltern counterpublic spheres in which the excluded groups can articulate their own identities and debate ideas.

Online social media in particular are linked with the creation of counterpublic spheres (Harlow, 2015a), as well as political participation, including voting, protests, and social movements (Park et al., 2009; Pasek et al., 2009; Valenzuela et al., 2012). While not originally created with activism in mind, social networking sites (SNS) like Facebook are now the most common gateway into activism, according to a 2009 survey by DigiActive (Brodock et al., 2009). For example, Zhang and colleagues (2010) found a positive relationship between SNS use and civic participation during the 2008 U.S. presidential election. Similarly, Lim (2012) found that protesters used Facebook to create online and offline networks that facilitated mobilization in Egypt during the Arab Spring. In Latin America, studies show that Facebook has played a central role in numerous protest movements, such as those in Guatemala (Harlow, 2012) and Colombia (Neumayer \& Raffl, 2008). Comparative studies of the United States and Latin America also show SNS to be integral to activists for both online and offline activism, as well as alternative media consumption and production (Harlow \& Harp, 2012; 2013).

\section{Digital inequalities}

The Internet no longer can be thought of as simply a tool to facilitate or amplify the efforts of an existing social movement. As Lievrouw (2011) suggested, ICTs are not just the medium, but perhaps they have become the "field" where activism actually takes place. However, any discussion of the democratic potential of the Internet must take into account digital inequalities, often referred to as the digital divide. Scholars suggest that the digital divide(s) include inequalities in skills, levels of interest, discretionary time, motivation, point and speed of access, and type of use (i.e. recreational vs. capital enhancing or liberating vs. not liberating) (Fuchs, 2009; Goldstein, 2007; Hargittai, 2008; Hargittai \& Hinnant, 2008; Harlow, 2015b; Van Dijk, 2005). Polat's (2005) 
review of the Internet and its impact on political participation showed that the "advantaged" populations, in terms of economic and education status-people who were already more likely to participate politically-are the ones who tend to benefit the most from the Internet. Previous research also classifies Facebook as an elite form of social media, with unequal participation resulting from differences in users' race, ethnicity, and parental education (Hargittai, 2007).

Unequal Internet access both within countries and between countries remains a problem throughout Latin America, as "the Internet is still a chimerical aspiration limited to the rich, indirectly subsidized by the state and exploited by corporations as a pure entertainment commodity" (Lugo-Ocando, 2008). Albornoz Tinajero (2007) argued that the digital divide will not be bridged until social gaps close. She cautioned, however, that new technologies are not a panacea, and assuring access will not automatically solve problems of social inequalities. At the time of this study, less than half, 42.9 percent, of the Latin American and Caribbean population had Internet access, and that number dropped to a mere 9.7 percent for Central America, and 24.5 percent in El Salvador (Internet World Stats, 2012).

\section{Social movement and media ecologies}

Recognizing that activists use a combination of analog and digital tools, media and social movement researchers have begun taking a more holistic approach to the study of how activists employ these tools to produce their own media and to interact with members of the media (Costanza-Chock, 2014; Mattoni, 2012; Treré, 2012). For example, Costanza-Chock (2012) speaks of social movement media cultures, or "the set of tools, skills, social practices and norms that movement participants deploy to create, circulate, curate and amplify movement media across all available platforms" (p. 375). His emphasis on "all available platforms" is reflected in his concept of transmedia organizing (Costanza-Chock, 2014), or using multiple platforms for participatory storytelling and media making that ultimately helps build movement identity. Similar to Costanza-Chock's concept of media culture, Treré (2012) used the concept of information ecology to explore an Italian student collective that was part of the Anomalous Wave movement. By 
considering the whole media environment, he showed how multiple technologies - what was used, how it was used, and what was not used - affected the entire movement system. Building on that idea, Treré and Mattoni (2016) reviewed existing research that employed a media ecological approach to the study of media and movements, and identified four benefits of using such an approach to better understand the interconnections of media and movements.

Noting that a "comprehensive conceptual framework that recognizes the intricacy of interactions between media and movements is lacking," Mattoni and Treré (2014) suggested the concepts of media practices, mediation, and mediatization as a way to "bridge the gap between social movement studies and media studies” (p. 252, p. 253). They contended that such an approach helps overcome a bias that focuses on just one medium or platform, as well as a bias that prioritizes the latest technological advance. Activist media practices (Mattoni, 2012) refer to activists' routine engagement with media tools to produce their own messages, as well as engagement with journalists and other media practitioners. Mediation (Martín Barbero, 1993) shifts the focus from the object (the media) to social processes (mediations), so that mediation in fact is a circular process of negotiating culture from the perspective of the popular and subaltern classes and their struggles. Lastly, mediatization is a long-term process describing the "interrelation between changes in media and communications on the one hand, and changes in culture and society on the other" (Couldry \& Hepp, 2013, p. 197).

For the purposes of this paper, Martín Barbero's concept of mediation - central to a great deal of Latin American communications research serves as a framework of analysis. Such an approach allows for "analyzing the links between communication practices and social movements" in order to understand how subaltern groups (re)appropriate, (re)interpret, and interact with media objects (Scolari, 2015, p. 1100). Scolari (2015) brings Martín Barbero's concept into this digital era with the notion of "hypermediations," which, rather than a focus on "new" media objects, rejects any technological determinism by bringing to the forefront new social 
processes and social transformations brought on by a networked culture. Lievrouw similarly turned to Martín-Barbero's mediation concept to help explain "communication as action" (2011, p. 230). For Lievrouw, mediation is comprised of reconfiguration (modifying and adapting technology to meet one's needs) and remediation (borrowing, adapting, or remixing existing content or structures to create something new), so that "media artifacts, practices, and arrangements become both the means and the ends of communication" (2011, p. 231). Using such an approach that takes into account the entire social movement and media ecology as a framework for understanding hypermediations, remediation, and reconfiguration in how Activista employed media tools and interacted with journalists helps answer Costanza-Chock's (2014) call for the retheorization of "movements and the media as interlocking systems" (p. 195).

\section{Methods}

This ethnographic case study involved in-depth interviews and participant observation, conducted from August 2012-August 2013 as part of a larger project on activism and alternative media and social media in El Salvador. In-depth, semi-structured interviews were conducted with 25 members of Activista, participants of the Cambio Global course, and workers with the Plataforma Global organization. Interview transcripts were analyzed using a grounded theory approach, wherein meaning and understanding are generated via interactions in social processes (Birks \& Mills, 2011; Blumer, 1986). Analysis involved reading and re-reading the transcripts, looking for the emergence of themes and patterns related to interview subjects' perceptions of how online social media impacted the Activista culture in terms of campaign strategies and communication techniques.

Four main themes surfaced during analysis. The first was that of social media as a form of alternative media for both bypassing the gatekeepers of mainstream media and getting mainstream media's attention. Second was the relationship between social media and visibility, legitimacy, and community. The third theme to materialize was that of a social media divide in terms of how Facebook was being used. The final theme was related to the challenges of incorporating social media for activism. These themes help 
us better understand how activists reconfigured and remediated tools and tactics, illuminating the links between movements and both alternative and mainstream media.

\section{Findings}

\section{Social media as alternative media}

Interviewees made it clear they believed social media served as alternative media platforms that gave them a voice that corporate, mainstream media typically had denied them. In other words, they reconfigured corporate social media sites to accommodate their subaltern purposes. One male activist and Plataforma Global worker called Facebook, Twitter, and other forms of social media "super alternative media. They're more than alternative: they're platforms where you can actually inform yourself." Unlike traditional media, such as television or newspapers, social media are platforms open to everyone, he said. They're platforms anyone can use to upload videos or information they believe is important or relevant. A female activist said she sees Activista's Facebook page as useful for informing people about news related to mining, water, gender rights, and other issues that typically don't make it into the mainstream media, or, if they do, are covered negatively or falsely. To counter misinformation in the media, she said she and others in the activist group post links to articles from alternative media outlets, or reports from NGOs and other activist organizations, and occasionally they'll also write their own articles. "Facebook is a place where you can ask a question and give an opinion, and also your opinion can be taken into account," she said.

Social media are important not only for activists, but in particular for youth activists, interviewees said. Mainstream media often forget about or ignore youth, especially youth from poorer communities, subjects explained. Another female activist said: "Adults have taken over the media spaces, which minimizes the voice of the youth. On the radio the most you might get is music for youth or for children, but never for youths' opinions. Opinion spaces are for adults, and music is for youths. And not just the radio, but also television and the press." So Activista turned to the Internet 
as a space for youth opinion, she said. "Facebook has become an alternative way for us youth to share news," a male activist said. Summing it all up, a female activist explained: "We're youth publishing things for youth, with creative content, and at the same time we're informing about problems that are completely overlooked in the mainstream media."

\section{Visibility, community, and legitimacy}

Beyond serving as a form of alternative media to bypass mainstream media, interviewees also saw social media as a way to attract the mainstream media's attention. For these activists, deploying social media was a way to reconfigure their relationship with journalists and, ultimately, the public at large. They saw one of social media's greatest strengths for activism as its ability to create visibility. Social media lack the legitimacy of traditional, mainstream media, but visibility in the media can help legitimize a movement or a group, a male worker at Plataforma Global said, noting that the media pay more attention when a cause has hundreds or thousands of followers on Facebook. "We have to be innovative and creative to get the media's attention," a female activist said. For subjects, that meant finding ways to use social media to amplify traditional - and not-so-traditional - tactics. For example, one female activist cited a flash mob the Activista group did during a women's rights march to call attention to the problem of femicide. When a whistle blew, people dropped to the ground as if dead. The message was "machismo kills." All of the television stations aired footage of the group's flash mob, and a video of the event was posted on Facebook, she said. "We as activists, as social groups, see social media in a different way," she said. "We have to take advantage of it in alternative ways." One Activista member noted the way the group has started making forays into YouTube, such as with a video of the group doing the Harlem Shake as part of an anti-mining campaign, in order to create visibility. Such videos attract attention and create a sense of anticipation that encourages people to participate in upcoming events. The activist said: "We were surprised at the enormous amount of people who came. Youth and adults, people with few economic resources, people from the country, it was an enormous quantity of diverse people, and everyone participated in the Harlem Shake. It was a lot of fun." Likes on Facebook mean that the group is attracting attention, even if not 
everyone who likes an event on Facebook actually attends that event, one male activist said: "Likes can help. They create visibility."

Visibility and legitimacy help develop a sense of community and solidarity, interviewees said. Sometimes the goal is not to reach people on the street, but rather for activists to come together in a march, or protest, or even a Facebook discussion or photo album as a way to encourage them to keep up the fight, interviewees explained. They also cited the way activists might work together to search for existing news stories, photos, or videos that they could then subvert to carry their own message. Individuals coming together in such a way - remediation - helped build identity and foster solidarity by making them feel their contributions mattered. This is part of the reason there is little debate on the Facebook page, they said: everyone already agrees with the cause. Or people post questions or seek information on the page. Instead of debate, then, the goal for social media has more to do with informing, mobilizing, and motivating, interviewees said. Social media unite people with common interests, allowing them to "like" what the other is going, ask questions, give advice, and thus create a sense of community, one male activist said. "You have virtual and real lives," he said, and social media help to combine the two. For example, he said he uses Facebook to inform and organize people from all over the country-not just the community in which he lives - into online social groups, which can then get together offline to try to change El Salvador for the better.

Still, using social media to generate visibility, legitimacy, and community is a two-edged sword, interviewees seemed to believe. For example, social media attention and social media participation do not always translate into offline participation. One activist lamented that while he sees Activista's Facebook posts generating likes, he rarely sees comments or any kind of debate. Videos and photos seem to get the most attention on Facebook, he said, but articles generate few, if any, likes or comments. Other activists said that in a recent march several university students approached them and said they had learned of the demonstration via Facebook, but in general interviewees said it was rare for them to encounter first-time 
protesters: most were already involved in various social organizations or protest groups, they said. Or, a lot of people who saw the event advertised on social media would show up to see what was going on but not really get involved. As a result, events could receive more than 400 "likes" on Facebook, but less than 100 people would actually attend, activists said. As one activist explained:

In terms of visibility, it has created a real boom. But we're also not reaching all the people we want to reach... because Facebook has a stigma. Generally, here, there's a misconception that youth are only using social media for non-productive things. So when people see that an organization or a network of youths doesn't use other media, only Facebook, then they label you as not being a real organization... Or as not having any power...So they don't take us seriously because they think Facebook is just for youths, and youths without a job or who only do non-productive things.

\section{Social media divide}

While some activists were concerned about being negatively labeled as "Facebook activists," they also acknowledged that there is a divide in who is using which social media platforms (and digital tools in general) and to what end, highlighting the importance of studying the entire media ecology of the movement, and not just one platform. Interviewees speculated that most youths had a Facebook account since the phone companies made the social networking site available as an app on cell phones, even when the owners did not otherwise have Internet access on their phones. And "everyone" had at least one cell phone, making Facebook a tool for the masses, they said. Twitter, however, was for the upper classes, they said, adding that they didn't use Twitter or even understand its purpose. Many also said they did not see how a 140-character restriction could result in activists successfully getting their message across. Activista found that for the group, Facebook works best, a female activist said. "We're all youth, and so we're all using Facebook. We already had accounts and were familiar with it, so it made sense to use it," she said. It's not like the group ever had a discussion about wanting to use Facebook and not wanting to use Twitter, she said. Rather, Facebook is what they knew and used and Twitter was the unknown. "With Facebook we can create groups where we can share information, propose 
activities, distribute responsibilities, all from our houses. It makes things easier." Facebook also was useful for the way YouTube videos, photos, and links to other news articles could be easily uploaded, as well as the space it afforded activists to publish "notes," meaning activists saw the platform more as a multi-dimensional, multi-media space, rather than just as a social networking site.

How people were using social networking sites, Facebook in particular, also was part of this social media divide. "It is difficult to reach the people who are just chatting or playing on Facebook," one male activist said. "It has become too easy to just sit at home and click something, which is bad for activism ... Digital tools are only valuable if they are helping us achieve our objective, to inform people and call them to action.” Another noted that many youth use Facebook "wrong, just clicking like, like, like, but never reading anything. Most youth aren't using it to protest or demonstrate.”

Most Salvadoran youth do not necessarily view social media as an important tool for activism or counter information, which is where civil society organizations and groups like Activista come into play, interviewees said. "Social organizations need to take responsibility and explain that Facebook, YouTube, were tools created by the rich and powerful to get richer, but that the youth can be trained to use them for a different purpose, more than just chatting or playing: to make their voices heard," a female activist said. Another commented: "The real power of these tools is to use them as a way to raise consciousness and generate action. This is what we're lacking in this country. Most youth are not doing this; they're using social media for other things, like playing. Which is fine. But there is a better use, which is raising consciousness."

Activists also can use social media to help attract youth who otherwise might not get involved in a cause, subjects said. One female activist explained:

It's a way of convincing youth, who have said to me, 'Before I used Facebook to view photos or to chat, but I like the way you all are using Facebook to mount activities and call for action,' so social media is a way to get these people involved. 
Similarly, another female activist said:

Most youth use Facebook, but they're not using it for social activism. So the idea is to use Facebook to bring them information they wouldn't read in newspapers or magazines or see on television. So to reach this population is very important. They're not informed, so they don't act.

As one male activist said, Facebook is:

a key tool if we're going to reach youth. If a day goes by that I don't check Facebook, I feel like I don't know what's going on in the world, that I'm missing important events or opportunities. We have to take advantage of Facebook, because it's where all the youth are...Youth here are not trained to be conscious that Facebook has another face, another use, not just for friends and fun, but a useful tool to achieve a lot of things. We just have to train them to see this.

Likewise, another male activist said, "What we're trying to do is educate people about the best way to use (social media). We believe that creating in people the capacity to use these tools is good for activism, for the social fight." In other words, activists were reconfiguring these platforms, shifting their purpose from entertainment and sociality to networking for a cause.

\section{Lack of strategy vs. lack of access}

The final theme to emerge from interviews was related to the challenges activists face in using online social media. Most activists, unsurprisingly, cited digital inequalities, including lack of Internet access and know-how, as the biggest obstacles to using social media for social change. Interestingly, though, many activists also said that a lack of social media strategy was in fact the greatest challenge, more so than the digital divide.

In general, one male Plataforma Global worker said, social media still are not very useful for convoking people simply because so many still lack Internet access, especially in rural areas. Members of Activista recognized that not everyone has Internet access, so the group designated coordinators (who have Internet access) in various departments of the country who 
can then serve as a liaison between local activists and the entire Activista network. "They have the responsibility to go to the communities and convoke the people who don't have access, or don't have a phone, and invite them personally," one female activist said. The liaisons "give us extra impact," another female activist said, adding that the group's events can only be successful if people with and without Internet access are able to participate. Activista also works with local NGOs, such as a national anti-mining coalition, to campaign in rural communities that often do not have Internet, let alone electricity or running water. These groups often pay for the transportation to bring people from rural areas into the capital city to participate in protests, a male activist said. The way these activists worked to find ways around barriers resulting from digital inequalities underlines the value of avoiding any technological determinism, whether in the positive or negative sense, as interviewees used tactics of remediation and reconfiguration to make digital content available as analog.

Thus, lack of access does not mean it is not worthwhile for activists to use the Internet in their campaigns, interviewees said. As one male activist noted, using the Internet is about power relationships and "reclaiming spaces." What they publish on social media from El Salvador can reach people living in countries where the mining companies are based, potentially allowing people from around the world to "show solidarity with the Salvadoran cause," he said. "They can go protest and pressure their governments to do something about what's going on in El Salvador... So yes, the Internet can be an important tool here, not just for local issues, but also international ones."

What Activista needs is a strategy for using social media for social change, other interviewees said. Using social media in liberating ways requires an analysis of who is visiting the group's pages; what they are reading, liking, and commenting on; and whether those same people who are active online are also active offline, they said. And as with any group, part of the problem lies in lack of resources, both human and material. If each person has one responsibility, and that person doesn't complete that responsibility, there is not a second person to take up that task, so it just does not 
get done, one male activist said. A male Plataforma Global worker said that part of the difficulty in using social media successfully is the lack of strategic thinking. "We don't always have clear whether we're using it to mobilize people or to inform them about the campaign." As part of the course, then, participants need to analyze why one event attracted hundreds of participants, and another just a handful, and then take those lessons and apply them.

Strategy also is important for deciding which tools to use and for what purpose. Sometimes an activist might want to create a video simply because it seems fun, but the time and effort might not be worth any potential benefits, a Plataforma Global worker said. Using the latest tool or app just to experiment with it is not the best use of limited time and resources, he added. As a result, often times the tactics created via digital tools seemed less successful — and thus were abandoned — simply because they were done without any strategic planning, he said. It's not that traditional tactics are necessarily better, but they are tried-and-true, so activists know they will work, whereas digital tactics do not yet have a long track record that activists can learn from. A female activist gave the example of members of Activista using their personal Facebook pages, rather than the group's official page, to call on legislators to approve an anti-mining law. Spreading the message out meant it wasn't as successful as it could have been, she said. "We didn't think about it," she said. "We need a strategy that tells us what we should be doing. We have activists working in radio, and we're doing the work of alternative media, but it's ironic because we don't have our own communications strategy." Part of the problem, though, is that most of them had undergone little digital training, they said, and so were unsure how to create a successful social media strategy. Further, in a digitally divided country like El Salvador, there were not a lot of cases of successful strategies for them to emulate.

\section{Discussion and Conclusions}

This ethnographic case study of the Salvadoran group Activista and the launch of its Todos Somos Agua campaign contributes to a burgeoning body of scholarship exploring the role of alternative/activists' media and social media in activism in digitally divided countries. This analysis offers 
a nuanced understanding of the links between activists' media and social media, which is particularly important given the changing media ecology in a post-Arab spring era in which activists increasingly are relying on digital tools. This study attempted to take a holistic media ecology approach by examining how the deployment of digital tools - social media in particular affected not just Activista, but its relationship with journalists and social media users at large. Further, through a lens of hypermediations (Scolari, 2015), this study showed how these Salvadoran youth activists reconfigured and remediated (Lievrouw, 2011) digital and analog/traditional tools and tactics to fit their particular needs and circumstances.

Broadly, this study asked two main research questions that shed light on activists' reconfiguration and remediation: How do Salvadoran activists view their relationship to social media, alternative media, and mainstream media? What are the perceived values, drawbacks, and challenges of using online social media for social change? Analysis of interviews with activists revealed four main themes: social media as alternative media; the relationship between Facebook and visibility, legitimacy, and community; a social media divide; and the challenges of the digital divide and a lack of a social media strategy.

First, as aforementioned, activists and mainstream media historically have shared a complicated relationship, wherein the media marginalize activists and their causes, and yet activists need the media's attention in order to gain legitimacy and public support (Downing, 2001; Gitlin, 1980). In part to counter mainstream media's negative images and to take control of their own messages, activists create their own media, or alternative media. As this study demonstrated, online social media, Facebook in particular, can be reconfigured as a form of alternative media in El Salvador. Activists said they believed Facebook offered a space that allowed people with non-mainstream views to voice an opinion. Facebook let them share news about mining, water contamination, and other social issues that they said otherwise the public would never learn about. Further, they saw Facebook as a sort of reclaimed media territory for youth, who normally are excluded by the mainstream media. 
The second theme that emerged in interviews was that of social media's role in creating visibility, legitimacy, and community. Interviewees said they were not concerned that Facebook had not generated any real political discussion or debate, because they saw the main purpose of the platform as aiding in generating visibility and creating a sense of community among youth activists. In other words, they were attempting to reconfigure their relationship with mainstream media and social media users at large by reconfiguring and remediating their own use of "new" and traditional tools and tactics. Activists said if they wanted to get the public's support they needed to attract media attention, which meant first creating a visible presence on social media. At the same time, however, subjects said they realized that a Facebook presence came with a drawback: lack of legitimacy. They did not want to be dismissed as mere social media activists. Interviewees saw power in using social media because not only did it give them a voice, it helped them raise awareness about their causes and stay connected with their fellow activists around the country in a way that was impossible prior to Facebook. They understood that not everyone who clicked "like" on a Facebook post would attend an offline protest or event, but they said reaching new offline participants was not necessarily their goal. Rather, for them, social media was a way for activists to support and encourage each other, motivating each other to keep up the fight. In this sense, then, Facebook was most useful for motivation and community building among current activists, and less useful for sharing information with the "unconverted" or reaching new audiences.

Another important finding of this study was that activists believed in a social media divide, or a division between who is using which social media platforms and for what purposes. Activists saw Facebook as a tool for the youth, and for all youth, regardless of education or income. In contrast, they believed Twitter was an elite tool, and thus less useful for reaching their target audience. When it came to how social media platforms were used, these activists distinguished between frivolous uses, such as looking at photos or playing games, and alternative, liberating uses focused on achieving social justice. This finding aligns with other studies of social media use in El Salvador (Harlow, 2015ab). Creating any real social change 
via social media in El Salvador first requires the youth to view social media in non-commercial ways, interviewees said. Any social media-driven protests in El Salvador are short-lived, they explained, because youth do not realize the full potential of Facebook, and it is up to groups like Activista to show the youth such alternative uses. This study thus extends the definition of the digital divide to account for not only which platforms are used by different social sectors of society, but also the ways in which those platforms are used. A better understanding of this social media divide is useful as activists consider implementing any Facebook or Twitter strategies.

Such strategies, or the lack thereof, competed with digital inequalities as the main obstacles activists said they face in incorporating online social media into their tactical toolboxes. Although just a quarter of the population had Internet access at the time of this study, activists said they found a way around the digital divide by using liaisons who had access to share information with those who did not. Further, they said that even though not everyone in El Salvador could support their causes online, social media allow them to reach international audiences that contribute to the creation of solidarity. Thus, despite the digital divide, they said they believed online social media were crucial to an activist's repertoire. Perhaps because they had found workarounds for the digital divide, many interviewees said a more pressing challenge was the lack of any social media strategy. In line with previous research that suggests strategy is essential for long-term success of a movement and social media social movements tend to lack such strategies (i.e., Bennett \& Segerberg, 2011), this study also found that a lack of strategy and lack of understanding about how to use different social media platforms means these activists were not using these online tools to their full liberating potential. Subjects said sometimes they experimented with a new tool just because it was the latest/greatest technology, but then because they did not have a clear plan in place about what they hoped to accomplish, they abandoned the tool. No strategy meant they often wasted their limited time and resources, and as a result often dismissed potentially useful tools. Also, this lack of strategy was tied to the digital divide: most activists interviewed had undergone little digital training and so were not adequately prepared to develop a social media strategy. 
This study offers an important contribution to our understanding of hypermediation (Scolari, 2015) and the way the digital and the analog work together in a social movement's media culture (Costanza-Chock, 2012) within a digitally divided country. This study is limited in that it is a case study, with findings subjective and open to the researcher's interpretation, and thus it is not generalizable. Still, such research is valuable for offering a nuanced understanding of a particular place in time. Future research should qualitatively and quantitatively examine other activist organizations' social media use in El Salvador, and expand the study to other countries in Latin America and other digitally divided areas of the world.

Ultimately this study shows how, despite digital inequalities, these Salvadoran youth activists reconfigured and remediated digital and analog tools and tactics in an effort to reconfigure and remediate their relationship with journalists and social media users at large, thus potentially undermining the gatekeeping control of mainstream media. Through reconfiguration and remediation, Activista managed to use social media as a mediated, hybridized, multi-dimensional mode of communication (Lievrouw, 2011; Martín Barbero, 1993). Considering that El Salvador remains a country reliant on 20th-century communication technologies, the online and the offline must fuse, requiring a hypermediated understanding of how the digital and the analog work in cohort to create potential new ways for activists to use alternative media, simultaneously bypassing the gates and attracting the attention of mainstream media, in order to push for social change. This study thus suggests that, even considering the tensions between alternative and mainstream media and between activists and mainstream media, these young activists deployed elements of the digital and the analog, the "new" and the traditional, using social media in non-hegemonic, alternative ways and thus furthering our understanding of how activists operate with an ever-evolving media ecology. 


\section{References}

Albornoz Tinajero, C. (2007). Nuevas tecnologías de la información y la comunicación para impulsar participación ciudadana en la legislación. In C. Albornoz Tinajero, V. Cabrera, K. Palacios, J. P. Ramírez \& D. Villafuerte (Eds.), Los usos de Internet: comunicación y sociedad (Vol. 2, pp. 111-188). Quito, Ecuador: FLACSO.

Anduiza, E., Cristancho, C., \& Sabucedo, J. M. (2013). Mobilization through online networks: The political protest of the indignados in Spain. Information, Communication \& Society.

Beers, D. (2006). The public sphere and online, independent journalism. Canadian Journal of Education, 29(1), 109-130.

Bennett, W. L., \& Segerberg, A. (2011). The logic of connective action. Digital media and the personalization of contentious politics. Information, Communication \& Society, 15(5), 739-768.

Birks, M., \& Mills, J. (2011). Grounded theory: A practical approach. Los Angeles, CA: Sage.

Blumer, H. (1986). Symbolic interactionism. Berkeley: University of California Press.

Brodock, K., Joyce, M., \& Zaeck, T. (2009). Digital activism survey report 2009. Retrieved from http://www.digiactive.org/wpcontent/ uploads/Research4_SurveyReport2009.pdf [Date accessed: November 12, 2015]

Chan, J. M., \& Lee, C.C. (1984). The journalistic paradigm on civil protests: A case study of Hong Kong. In A. Arno \& W. Dissanayake (Eds.), The news media in national and international conflict (pp. 183-202). Boulder, CO: Westview.

Costanza-Chock, S. (2012). Mic check! Media cultures and the Occupy movement. Social movement studies, 11(3-4), 375-385. 
Costanza-Chock, S. (2014). Out of the shadows, into the streets! Transmedia organizing and the immigrant rights movement. MIT press. Available at SSRN:http://ssrn.com/abstract=2516003 [Date accessed: November 12, 2015]

Couldry, N., \& Curran, J. (Eds.). (2003). Contesting media power: Alternative media in a networked world. Lanham, MD: Rowman \& Littlefield.

Couldry, N., \& Hepp, A. (2013). Conceptualizing mediatization: Contexts, traditions, arguments. Communication Theory, 23, 191-202.

Downing,J. (2001). Radical media: Rebellious communication and social movements. Thousand Oaks: Sage Publications.

Fraser, N. (1990). Rethinking the public sphere: A contribution to the critique of actually existing democracy. Social Text, 25/26, 56-80.

Fuchs, C. (2009). The role of income inequality in a multivariate cross-national analysis of the digital divide. Social Science Computer Review, 27(1), 41-58. doi: 10.1177/0894439308321628

Gitlin, T. (1980). The whole world is watching: Mass media in the making o unmaking of the new left. Berkeley and Los Angeles: University of California press.

Gurevitch, M., \& Blumler, J. (1990). Political communication systems and democratic values. In D. Graber (Eds), Media Power in Politics (pp. 24-35). Washington, DC: Congressional Quarterly Press.

Hall, S. (1986). The problem of ideology: Marxism without guarantees. Journal of Communication Inquiry, 10, 28-44.

Hargittai, E. (2007) Whose space? Differences among users and nonusers of social network sites. Journal of Computer-Mediated Communication, 13. 
Hargittai, E. (2008). The digital reproduction of inequality. In Grusky, D. (Ed.) Social Stratification. Boulder, Colorado: Westview Press.

Hargittai, E., \& Hinnant, A. (2008). Digital inequality: Differences in young adults' use of the internet. Communication Research, 35(5), 602-621.

Harlow, S. (2012). Social media and social movements: Facebook and an online Guatemalan justice movement that moved offline. New Media \& Society, 14(2), 225-243.

Harlow, S. (2015a). Twitterati as instruments of change? Reappropriating social media for dialogue and action via El Salvador's citizen debate site Política Stereo. International Journal of Communication, 9, 20.

Harlow, S. (2015b). Beyond representation: Exploring participation in and through technology at an alternative newspaper in El Salvador. Cuadernos.info, (37), 35-47.

Harlow, S. \& Harp, D. (2012). Collective Action on the Web: A cross-cultural study of social networking sites and online and offline activism in the United States and Latin America. Information, Communication \& Society, 15, 196-216.

Harlow, S. \& Harp, D. (2013). Alternative media in a digital era: Comparing news and information use among activists in the United States and Latin America. Communications Society/Comunicación y Sociedad, 4(26), 25-51.

Internet World Stats. (2012). Retrieved March 11, 2014, from http://www. internetworldstats.com/stats12.htm\#central

Kessler, L. (1984). The dissident press: Alternative journalism in American history. Beverly Hills, CA: Sage Publications.

Kidd, D. (2003). Indymedia: A new communications commons. In B. McCaughney \& M. Ayers (Eds.), Cyberactivism: Online acts in theory and practice (pp. 47-69). New York: Routledge. 
Lievrouw, L. A. (2011). Alternative and activist new media. Cambridge: Polity Press.

Lim, M. (2012). Clicks, cabs and coffee houses: Social media and oppositional movements in Egypt, 2004-2011. Journal of Communication, 62, 231-248.

Lugo-Ocando, J. (2008). An introduction to the maquilas of power: Media and political transition in Latin America. In J. Lugo-Ocando (Ed.), The media in Latin America (pp. 1-12). New York: McGraw-Hill Open University Press.

Macafee, T., \& De Simone, J.J. (2012). Killing the bill online?: Pathways to young people's protest engagement via social media. Cyberpsychology, Behavior, and Social Networking, 15(11), 1-6.

Martín-Barbero, J. (1993). Communication, culture and hegemony: From the media to mediations. London: Sage.

Mattoni, A. (2012). Media practices and protest politics: How precarious workers mobilize. Farnham, UK: Ashgate.

Mattoni, A., \& Treré, E. (2014). Media practices, mediation processes, and mediatization in the study of social movements. Communication theory, 24(3), 252-271.

McLeod, D. M. (2007). News coverage and social protest: How the media's protect paradigm exacerbates social conflict. Journal of Dispute Resolution, 185-94.

McLeod, D. M. \& Hertog, J. K. (1999) Social control, social change and the mass media's role in the regulation of protest groups. In D. Demers \& K. Viswanath (Eds.), Mass media, social control and social change: A macrosocial perspective (pp. 305-330). Ames, IA: Iowa State University Press. 
McLeod, D. M., \& Hertog, J. K. (1992). The manufacture of 'public opinion' by reporters: Informal cues for public perceptions of protest groups. Discourse \& Society, 3(3), 259- 275.

McLeod, D., \& Detenber, B. (1999). Framing effects of television news coverage of social protest. Journal of Communication, 49(3), 3-23.

Neumayer, C., \& Raffl, C. (2008). Facebook for protest? The value of social software for political activism in the anti-FARC rallies. DigiActive Research Series. Retrieved August 15, 2009, from http://www.digiactive.org/wp-content/uploads/research1_neumayerraffl.pdf

Park, N., Kee, K.F., \& Valenzuela, S. (2009). Being immersed in social networking environment: Facebook Groups, uses and gratifications, and social outcomes. CyberPsychology \& Behavior, 12, 729-733.

Pasek, J., More, E., \& Romer, D. (2009). Realizing the social Internet? Online social networking meets offline civic engagement. Journal of Information Technology and Politics, 6, 197-215.

Pérez, R., \& Carballo, W. (2013). El mapa de medios en El Salvador. Todo queda en familia. In Ó. Pérez (Ed.), Comunicación, información y poder en El Salvador: Claves para la democratización (pp. 45-76). San Salvador: Fundación Comunicándonos.

Polat, R. K. (2005). The Internet and political participation: Exploring the explanatory links. European Journal of Communication, 20(4), 435-459.

Postmes, T., \& Brunsting, S. (2002). Collective action in the age of the Internet: Mass communication and online mobilization. Social Science Computer Review, 20(3), 290-301.

Rockwell, R., \& Janus, N. (2003). Media power in Central America. Urbana: University of Illinois Press. 
Rodriguez, C. (2001). Fissures in the mediascape. Cresskill, NJ: Hampton Press.

Scolari, C. A. (2015). From (new) media to (hyper) mediations. Recovering Jesús Martín-Barbero's mediation theory in the age of digital communication and cultural convergence. Information, Communication \& Society, 18(9), 1092-1107.

Simpson Grinberg, M. (1986). Trends in alternative communication research in Latin America. In R. Atwood \& E. G. McAnany (Eds.), Communication \& Latin American society: Trends in critical research, 19601985 (pp. 165-189). Madison, WI: University of Wisconsin Press.

Treré, E. (2012). Social movements as information ecologies: Exploring the coevolution of multiple Internet technologies for activism. International Journal of Communication, 6, 19.

Treré, E., \& Mattoni, A. (2016). Media ecologies and protest movements: main perspectives and key lessons. Information, Communication \& Society, 19(3), 290-306.

Tufekci, Z., \& Wilson, C. (2012). Social media and the decision to participate in political protest: Observations from Tahrir Square. Journal of Communication, 62, 363-379.

Valenzuela, S., Arriagada, A., \& Scherman, A. (2012). The social media basis of youth protest behavior: The case of Chile. Journal of Communication, 62(2), 299-314.

Van Dijk, J. (2005). The deepening divide: Inequality in the information society. Thousand Oaks: Sage.

Wilson, C., \& Dunn, A. (2011). The arab spring: Digital media in the Egyptian revolution: Descriptive analysis from the Tahrir data set. International Journal of Communication [Online], 5. Retrieved from http://ijoc.org/ojs/index.php/ijoc/article/view/1180/682 [Date accessed: November 12, 2015] 